\title{
Real Effects of Financial Distress: The Role of Heterogeneity*
}

\author{
Francisco Buera $^{\dagger} \quad$ Sudipto Karmakar ${ }^{\ddagger}$
}

\begin{abstract}
How severe are the real consequences of financial distress caused by sovereign debt crisis? What are the channels through which sovereign debt crisis affect banks and firms, and vice versa? Does firm heterogeneity matter? If yes, what are the important dimensions of heterogeneity? Using micro data from Portugal during the sovereign crisis starting in 2010, we address these questions. We make use of the Bank of Portugal's detailed credit registry database together with bank and firm balance sheets and income statements to conduct this analysis.

We first study the direct effect of the sovereign crisis on bank balance sheets by analyzing the differential impact on firms that had relations with banks who were more exposed to the sovereign (pre-crisis). We find that more fragile firms that had relations with more exposed banks contracted more than their counterparts. Specifically we find leverage and maturity structure of debt to be important dimensions of heterogeneity determining a firm's fragility. Highly leveraged firms and those that had a larger share of short term debt contracted more during the sovereign debt crisis. We analyze firm performance on the basis of growth rate of employment, assets, liabilities and usage of intermediate commodities. We show that our findings are consistent with a simple model of leverage and maturity choice.

We then document the spillover effects across firms that are mediated through the banking sector. To do this, we focus on the set of firms that were current on all their loans through the crisis, i.e., the set of performing firms. We find that performing firms that had relations with banks whose corporate loan balance sheet deteriorate by more were more affected by the sovereign crisis. Again, highly leveraged firms and those that had a larger share of short term debt contracted more during the sovereign debt crisis.
\end{abstract}

JEL Codes:

Key words: Sovereign debt, Leverage, Maturity structure, Spillovers.

\footnotetext{
${ }^{*}$ We would like to thank Manuel Adelino, Jeff Campbell, Simon Gilchrist, Francois Gourio, Narayana Kocherlakota, Steven Ongena and seminar participants at the BIS, the Bank of Portugal, the Chicago Fed, and the Bank of Hungary for helpful comments and discussions. The views expressed are those of the authors and do not reflect the views of the Federal Reserve Bank of Chicago, the Federal Reserve System, the Banco de Portugal or the Eurosystem.

${ }^{\dagger}$ Federal Reserve Bank of Chicago, email: francisco.buera@chi.frb.org

${ }_{\ddagger}^{\ddagger}$ Banco de Portugal \& UECE, email: Sudipto.Karmakar@bportugal.pt
} 